\title{
Whey Utilisation: Sustainable Uses and Environmental Approach
}

\section{Elizabeta Zandona'®e, Marijana Blažić ${ }^{1}$ and Anet Režek Jambrak*๑ \\ 'Karlovac University of Applied Sciences, Trg J.J. Strossmayera 9, 47000 Karlovac, Croatia \\ ${ }^{2}$ Faculty of Food Technology and Biotechnology, Pierottijeva 6, 10000 Zagreb, Croatia}

Received: 4 September 2020 Accepted: 20 April 2021

(i)

*Corresponding author:

Phone: +38514605287

Fax: +38514836083

E-mail: anet.rezek.jambrak@pbf.unizg.hr

\section{SUMMARY}

The dairy industry produces large amounts of whey as a by- or co-product, which has led to considerable environmental problems due to its high organic matter content. Over the past decades, possibilities of more environmentally and economically efficient whey utilisation have been studied, primarily to convert unwanted end products into a valuable raw material. Sustainable whey management is mostly oriented to biotechnological and food applications for the development of value-added products such as whey powders, whey proteins, functional food and beverages, edible films and coatings, lactic acid and other biochemicals, bioplastic, biofuels and similar valuable bioproducts. This paper provides an overview of the sustainable utilisation of whey and its constituents, considering new refining approaches and integrated processes to convert whey, or lactose and whey proteins to high value-added whey-based products.

Key words: whey utilisation, whey proteins, lactose recovery, biorefineries

\section{INTRODUCTION}

Due to the continuous growth of the dairy industry, large quantities of by-products are produced, mainly whey. Cheese whey is a strong organic effluent that can pose a risk to the environment if not properly managed. The chemical oxygen demand (COD) of cheese whey can range from 50 to $80 \mathrm{~g} / \mathrm{L}$, while biochemical oxygen demand (BOD) varies from 40 to $60 \mathrm{~g} / \mathrm{L}$ (1). Lactose, fat and proteins constitute the main fraction of the organic load. In the absence of sustainable practices, whey is considered the most important environmental pollutant of the dairy industry because a large amount of whey is disposed of as wastewater and is associated with serious environmental hazards (2). The disposal of whey also represents a significant loss of potential nutrients and energy, so in order to utilise the nutritional value of whey and at the same time mitigate the harmful effects of disposal in the environment, it is important to direct whey management towards a cost-effective and sustainable way of utilisation and directing it into the production of novel valuable products. At the UN Summit on Sustainable Development held in New York in September 2015, 'Transforming our World', the UN Agenda 2030 for Sustainable Development (3) was adopted as a key global political platform for addressing many of today's challenges in their interconnected economic, social, environmental and political security dimensions. The main backbone of this ambitious development agenda is the 17 sustainable development goals (SDGs) elaborated in 169 closely related sub-goals, some of which are related to sustainable waste management of all forms of waste throughout their life cycle, reduction of emissions to the air, water and soil, and reduction of waste generation with increased share of recycling and reuse (3). In this sense, the attitude towards whey has changed from a waste to a valuable dairy by-product, and series of studies have been conducted to find feasible, environmentally friendly whey utilisation alternatives, instead of just disposing the whey in the field (4). The high nutritional value of whey and its health benefits have resulted in nearly $50 \%$ of residual whey being recycled for the production of value-added products in the food and chemical industries (5). The traditional use of whey and its constituents in human and animal nutrition as a health promoter has been 
reported previously, with several biotechnological approaches and process technologies developed to convert this side-product into a source of high-value nutritional components (6). New methods of whey utilisation are contributing to the advancement of applied technology. Ultrafiltration and nanofiltration have strengthened the utilisation of whey streams, while fermentation processes for conversion of whey into high-value products have emerged as a potential pathway for biorefinery development (7). The simultaneous incorporation of several work units in one process is a great economical and sustainable alternative to using whey for the creation of more valuable products, thus reducing the impact of whey on the environment.

The aim of this study is to give an overview of the sustainable use of whey, as well as lactose and proteins from whey to produce high value-added products and to identify which SDGs can benefit from the reuse of dairy waste and by-products. Recent advances and new findings in refining technologies for sustainable whey management are elaborated, and environmental practices focused on reducing the ecological footprint are considered.

\section{WHEY COMPONENTS AND THEIR BENEFITS}

Whey can be defined as the yellow-green watery part of milk (serum) that remains when the curd is separated during cheesemaking. It accounts for about $85-90 \%$ of the volume of milk and contains about $55 \%$ of the nutrients in milk. The average content of whey dry residue is: $70 \%$ lactose (depending on the acidity of the whey), $14 \%$ proteins, $9 \%$ minerals, $4 \%$ fats and $3 \%$ lactic acid (8). Based on the method of the milk protein coagulation, it is classified into two categories: sour and sweet whey. Sour whey, with a $\mathrm{pH}<5$, is a by-product of fermentation or processes using the addition of organic or mineral acids for casein coagulation, e.g. the production of fresh cheese or the production of industrial casein. Sweet whey is derived from the production of cheese or certain casein products where processing is based on the coagulation of casein by rennet, an industrial coagulant containing chymosin or other casein-coagulating enzymes (proteolytic enzymes) with a $\mathrm{pH}=6-7$ (9). It contains several value-added commodities due to its high level of fat, lactose and proteins, while sour whey contains higher levels of lactic acid, calcium and phosphorus (10) and is usually combined, stored and treated with plant's primary washing waters. Although the sour whey is low in lactose and is further diluted with the wash streams, it still has high levels of COD and total organic carbon (TOC) and poses a high risk to the environment when discharged as effluent. Therefore, it should be subjected to a purification process before discharge into the receiver (11). In general, whey has high nutritional value and is easily digestible and assimilable. It is also considered an excellent source of functional proteins and a rich source of vitamins $\mathrm{B}$, minerals (Ca, $\mathrm{P}, \mathrm{Na}, \mathrm{K}_{1} \mathrm{Cl}^{-}, \mathrm{Fe}, \mathrm{Cu}, \mathrm{Zn}$ and $\mathrm{Mg}$ ) and lactose (2,12). Because of excellent nutritional and functional properties of whey solids, a substantial portion of whey is processed into whey powders, while the remainder is used for the production of sweet whey powder, demineralised whey, delactosed whey, whey protein concentrate (WPC), whey protein isolate (WPI) or lactose (6).

\section{SUSTAINABLE UTILISATION OF WHEY AND ITS COMPONENTS}

The dairy industry is recording a steady increase in the amount of produced whey, so new sustainable methods of whey utilisation must be sought to reduce the environmental impact of whey disposal and to reduce high operating cost of whey processing. To implement sustainable whey management, a better understanding of the environmental and social impacts of products and services is needed, both of product life cycles and how they are affected by use within lifestyles. There are several directions of sustainable whey management which are mostly oriented to biotechnological and food applications for the development of value-added products such as whey powder, functional foods and beverages, lactic acid, bioethanol, bioplastics, biogas, etc. Large quantities of whey can be processed into bioethanol, while for smaller quantities, it is most economical to produce fermented or unfermented whey-based beverages. In that way sustainable whey management could contribute to the fulfilment of the Agenda 2030 6th SDG: clean water and sanitation, 9th SDG: industry, innovation and infrastructure and 12th SDG: responsible consumption and production and its subgoals: water quality improvement, enhancement of the infrastructural sustainability, global food waste and food losses mitigation, and waste generation reduction (3). Defining whey as a valuable raw material and its further processing into high-value products can contribute to minimizing the release of hazardous substances to the environment and thus reduce environmental pollution. It could also halve the proportion of untreated wastewater and substantially increase its recycling and safe reuse globally. Furthermore, resource efficiency would be increased, clean and environmentally friendly technologies and industrial processes would be adopted, while global per capita waste and food losses in production and supply chains would be halved.

\section{Processing of liquid whey}

Whey powders

The production of whey powders is one of the most popular ways of utilising liquid whey. Even though drying of whey accounts for $70 \%$ of its annual processing (12), the development of new technologies has led to exploring alternative ways to transform whey into important value-added products. The production of whey powders usually involves several processes: a) clarification of whey, b) separation of cream and pasteurization, c) concentration of total solids (40-60\% by using evaporation), d) lactose crystallization, and e) drying of whey (removal of water by spray drying). If 
lactose crystallization is not carried out, the solid mass of the formed bulk powder is suitable only for animal feed as an inexpensive source of high-quality proteins and carbohydrates. Implementation of different drying techniques does not produce residues that need to be treated separately, and the quality of the whey powder is preserved during transportation or further manipulation. On the other hand, it requires the high capital investment to purchase the necessary equipment and consumes a lot of energy during production. One of the disadvantages is also that whey powders have a relatively low selling price compared to whey protein concentrates (WPC). However, because of the high nutritional value, whey powder products are used in very different areas of the food industry; the most widespread use is as an additive in the production of a wide range of foods and beverages (e.g. infant formula, meat products, beverages, soups, sauces, toppings, creamers, nut coatings, pressed nuts, cheese-based sauces, potato chips, savoury flavours and savoury pastries, special bakery products such as pizza, biscuits and macaroni, and the manufacture of soufflés and cakes) (13). Whey powder can also be used as an adsorbent and as a fat and oil carrier. When producing the higher-grade whey protein powders, the whey is additionally treated by membrane separation, usually ultrafiltration or diafiltration (8). Foods made with the addition of whey powder may have improved sensory properties and enhanced physical characteristics (foaming or acid stability). However, such foods may also have the same texture, taste and appearance as cheese-containing foods (6). There are a variety of beverages with whey as the main or major ingredient, along with beverages based on whey-derived ingredients, i.e. WPC, WPI and whey protein hydrolysate (WPH) (7). These ingredients are added to beverages with high protein content, mainly sports drinks and drinks for the malnourished. Every year a small amount of WPC is produced, WPI even to a lesser extent, while the residual permeate can be recycled for lactic acid, bioethanol or lactose production (12).

\section{Functional foods and beverages}

Functional foods and beverages are one of the most ambitious and innovative categories in the food industry, continuing to generate a great deal of interest among many consumers as they offer health benefits beyond basic nutrition. Whey and its components are increasingly used as functional ingredients in dietary and health products, while bioactive proteins are more often used in both the pharmaceutical and nutritional industries (8). To date, researchers have focused on investigating the production of whey-based beverages from native sweet and sour whey, or from powdered, deproteinised and thinned whey (14). The largest dairy companies in the world have already introduced a new generation of whey-based products (12). Although the production of such beverages is proving to be the most economical approach to the use of whey in human nutrition, there are several difficulties regarding their production, such as susceptibility to microbial spoilage due to the high water content, and the sensitivity of whey proteins to heat treatments at temperatures above $60^{\circ} \mathrm{C}$. Most whey proteins precipitate after the usual thermal treatment of whey (at $72{ }^{\circ} \mathrm{C}$ for $15-20 \mathrm{~s}$ ) (2). Therefore, much research aims to implement non-thermal techniques in the production of whey beverages, such as membrane separation, high-intensity ultrasound or supercritical carbon dioxide technology. The implementation of non-thermal methods in the production of whey beverages overcomes the above-mentioned difficulties, and improves the properties of existing products (15-18).

\section{Biogas}

Considering the new environmental rules, the use of digestion processes has become a quite common alternative in the treatment of agro-industrial residues. In addition, waste digestion produces biogas that can be used in power generation, resulting in both environmental and economic benefits. Because of its high organic and low buffer capacity, anaerobic digestion of whey leads to prompt acid evolution and low biogas production, so to increase the productivity whey should be mixed with other types of wastes and/or manure (6). Antonelli et al. (19) reported the tremendous energetic potential of biogas produced when cheese whey is digested using swine wastewater as inoculum. They noted $53.11 \%$ reduction of volatile solids and biogas yield of $270 \mathrm{~L}$ with $63 \%$ methane during digestion at $32{ }^{\circ} \mathrm{C}$, and $45.76 \%$ volatile solid reduction and biogas yield of $171 \mathrm{~L}$ with $61 \%$ methane at $26^{\circ} \mathrm{C}$.

Waste minimization issues bring considerable attention to the development of sustainable fuels from renewable sources, also known as 'green technology'. Hydrogen is a so-called 'clean' energy that does not generate greenhouse gasses or cause acid rain. Due to its low solubility, it is easy to hydrolyse and purify, it has high energy efficiency and can be used directly in fuel cells to generate electricity. It is a by-product of the anaerobic conversion of organic wastes by anaerobic and photosynthetic microorganisms into organic acids which are then used for methane generation (20). Fermentative bacteria, anaerobic bacteria and cyanobacteria are the three most common types of microorganisms that produce hydrogen. Lactose-rich wastes or by-products from the dairy industry have huge potential for biohydrogen production. Numerous operating parameters and configurations of bioreactors have been investigated in order to produce biohydrogen using cheese whey. Most studies addressed renewable feedstock processing using mono-digestion of a single substrate with a lower yield of $\mathrm{H}_{2}$, probably due to the poor buffering capacity of substrates and nutrient limitation (21). To overcome these limitations, some researchers suggested the use of co-digestion of two or more substrates for dark fermentation. Rosa et al. (22) studied the influence of inoculum sources and the co-fermentation of cheese whey with glucose. Lima et al. (23) used an anaerobic sequencing batch reactor operated with immobilized biomass on an inert support 
(AnSBBR) and noted that the filling time had no effect on biohydrogen production, while the feed concentration showed an optimal point for the COD of $5400 \mathrm{mg} / \mathrm{L}$, reaching values of $0.80 \mathrm{~mol} \mathrm{H}_{2}$ per mol lactose and hydrogen production of $660 \mathrm{~mL} /(\mathrm{L} \cdot$ day). They were also the first to report a strong influence of temperature on biohydrogen production, with the lowest temperature $\left(15^{\circ} \mathrm{C}\right)$ showing the best results $(1.12 \mathrm{~mol}$ $\mathrm{H}_{2}$ per mol lactose). Rivera et al. (24) showed that microbial electrolysis cells can be considered for the treatment of cheese whey to obtain biohydrogen. Blanco et al. (25) described the anaerobic structured-bed reactor (ASTBR) as a likely alternative for fermentative biohydrogen production from cheese whey, offering better performances than conventional fixed-bed reactors. They achieved a biohydrogen yield of $2.4 \mathrm{~mol} \mathrm{H}_{2}$ per mol lactose with an average yield of (1.4 \pm 0.7$) \mathrm{mol} \mathrm{H}_{2}$ per mol lactose over a 32-day period.

\section{Lactose recovery and utilisation}

Lactose (4-O- $\beta$-D-galactopyranosyl-D-glucose) is a basic component of whey solids (70-72\% total solids) and a very important energy source, making whey a potential raw material for the production of lactose as well as whey-based value-added products. From a health and nutritional point of view, lactose presents many benefits because it acts like dietary fibre and has prebiotic properties. In that manner, lactose facilitates the intestinal absorption of various minerals such as calcium, phosphorus and magnesium (26). It is also used as a nutrient source and substrate for the production of lactic acid and short carbon cycle fatty acids (SCFA) by intestinal bacteria, thereby establishing a mildly acidic reaction in the intestine and preventing the growth and proliferation of harmful bacteria (27). Also, it has a lower impact on blood sugar levels due to the low glycaemic index (half that of glucose) (28). Lactose may be recovered from whey by isolation from deproteinised whey (e.g. whey permeate obtained by ultrafiltration) using several methods: concentration of whey by evaporation, crystallization of lactose from concentrated whey (29) and separation of the obtained crystals by centrifuge or decanter (13). Lactose is the main component causing high BOD and COD levels in whey, so its recovery could reduce the BOD value by more than $80 \%$ (30). In this regard, lactose recovery could solve waste utilisation problems and environmental issues, respectively. Depending on its quality, the recovered lactose may further be supplied to the food, pharmaceutical, dairy and beverage (e.g. food-grade or pharmaceutical-grade) industries. Generally, it is used in the food and confectionery industries, above all in the baking industry as a crust browning promoter, and in the pharmaceutical industry as an excipient. Further, it is possible to produce new whey-based products by the degradation of lactose by microorganisms. Various biotechnological processes have been developed to recover lactose from whey and its further processing into products of industrial importance, e.g. organic acids and alcohols, such as lactic and citric acids, ethyl alcohol, kefir-like fermented whey beverages, single cell proteins, probiotic starter cultures, biogas, bioplastic and ethyl lactate (31).

\section{Lactic acid}

Lactic acid (LA; 2-hydroxypropanoic acid) is a promising platform chemical existing as two isomers, $L(+)$ and $D(-)$. Both of them can be produced biotechnologically, but only $L(+)$ isomer can be used in the food industry, because $D(-)$ is harmful to humans (32). In contrary, D(-) has a range of applications in the production of polylactic acid-based polymers (PLA), can be converted into several chemicals of industrial importance such as pyruvic acid, acrylic acid, 1,2-propanediol and lactate ester (33). LA and its derivatives have long been applied in food, pharmaceutical, textile, leather and chemical industries, primarily as preservatives and acidifiers. Lately, its production increased due to the application in the production of the environmentally friendly biodegradable polymers (PLA) (6) with the intention of replacing significant amounts of petroleum-based plastics and contributing to climate change mitigation goals. Lactose can be effectively converted to lactic acid by fermentation using bacteria, fungi and yeast (34). It is a fermentation product of a wide group of microorganisms (35), e.g. Lactobacillus, Bacillus, Enterococcus, Lactococcus, Pediococcus, Streptococcus and Candida, and filamentous fungi Rhizopus oryzae (33). Only few of them are used by the industry starting with native LA producers Lactobacillus delbrueckii and Sporolactobacillus, recombinant organism Escherichia coli, Bacillus coagulans, Corynebacterium glutamicum and B. licheniformis (36). Kluyveromyces marxianus var. marxianus has also been successfully used for LA production (13). LA is primary synthetised from pure and expensive lactose, glucose or sucrose. Because of the high prices of pure raw materials, research is directed towards more economically and environmentally friendlier approaches, e.g. obtaining LA from waste effluents, such as whey (37). Whey needs to be pretreated by membrane techniques prior to the production of LA to reduce its protein content and increase the concentration of lactose and mineral salts. Therefore, precipitating whey proteins at a high temperature, and then using the remaining lactose as the carbon source for fermentation with some other nitrogen supplement such as yeast extract represents the main LA production method (38). When utilising a complex feedstock such as whey, which contains a mixture of carbohydrates, fermentation using mixed cultures is recommended to provide the desirable combinations of metabolic pathways for better carbohydrate conversion into LA (39). Lactic acid bacteria have limited ability to synthesize amino acids and vitamins $B$, so nutrient supplementation is a key factor limiting the process efficiency, especially in industrial scale application. In that manner, carbohydrates from whey are metabolised with the addition of nutrients such as yeast extract, peptone, or corn steep liquor as nitrogen sources (40). Liu et al. (38) established a simple and economic Dlactic acid production from cheese whey powder by employing Lactobacillus bulgaricus CGMCC 1.6970 and obtained a 
high D-lactic acid titre and productivity of $113.18 \mathrm{~g} / \mathrm{L}$ and $2.36 \mathrm{~g} /(\mathrm{L} \cdot \mathrm{h})$, respectively. To provide an additional source of nitrogen and replace the yeast extract to a large extent, they hydrolysed the CW domain containing proteins by proteases prior to the fermentation. Reduced nutrient supplementation and more efficient and sustainable LA production can be achieved by using genetically or metabolically modified strains with new or improved properties or by co-cultivation with strains that provide important nutrients. Zhang and Vadlani (41) used a co-culture of L. brevis ATCC 367 and L. plantarum ATCC 21028 strains for LA production from biomass-derived sugars, which increased the LA yield significantly (from 0.52 to $0.80 \mathrm{~g} / \mathrm{g}$ ), with a lower by-product accumulation. Sahoo and Jayaraman (42) described D-LA production from whey permeate by Lactobacillus delbrueckii and engineered Lactococcus lactis co-culture and also noted the enhancement in the yield of $D-L A$. To improve the titre and productivity of $D-L A$, the authors pointed out the need for fed-batch process design. Further performance improvement of the D-LA production process could be accomplished by upgrading the repeated batch and fed-batch fermentation to continuous mode (43), including cell recycling or by implementing the immobilized cells in fixed or fluidized bed bioreactors (Table 1) (37). Ziadi et al. (50) developed kinetic modelling of biomass and lactic acid production by Enterococcus faecalis SLT13 during batch culture in M17 and hydrolysed cheese whey in 2- and 20-litre bioreactors.

The use of whey and similar complex substrates for LA production results in a series of impurities in the fermentation broth. Therefore, to obtain pure LA, large-scale downstream processing is required, which includes several membrane separation processes (e.g. micro- and nanofiltration, electrodialysis with monopolar and bipolar membranes or concentration by water evaporation) (33). Immobilisation technology and cell recycling may improve the process by increasing cell density in the bioreactors and facilitate purification in downstream process, especially in continuous systems.

\section{Bioplastic}

The interlinkage of biotechnology processes is a key strategy in maximizing the use of agro-industrial wastes and increasing the potential revenue of the entire bioprocessing chain in the production of bioplastics (Table 2). Using cheese whey as a substrate for bioplastic production has lately come in focus, as the lactose present in whey permeate can be easily converted into polyhydroxyalkanoates (PHAs) and polylactic acid (PLA) (55). The bioplastics thus produced can be further used in the packaging, spraying materials, device materials, electronic products, agricultural products, automation products, chemical media and solvent industries.

\section{Polyhydroxyalkanoates}

Polyhydroxyalkanoates (PHAs) are biopolyesters synthesised as carbon and energy reserve by aerobic bacteria and accumulated as intracellular granules under growth-limiting and carbon excess conditions. PHAs include polyhydroxybutyric acid (PHB), polyhydroxyvaleric acid (PHV), 3-hydroxy-2-methylbutyrate (3H2MB) and 3-hydroxy-2-methylvalerate $(3 \mathrm{H} 2 \mathrm{MV})(40)$. PHAs have mechanical and physical

Table 1. Lactic acid production using cheese whey-based medium

\begin{tabular}{|c|c|c|c|}
\hline Substrate & Microorganism & Fermentation type & Ref. \\
\hline Cheese whey & $\begin{array}{l}\text { Lacticaseibacillus casei BL23 } \\
\text { L. casei BL71 (BL23 ccpA:::erm) }\end{array}$ & Stirred tank batch fermentation & (44) \\
\hline Cheese whey & Polyvinyl alcohol (PVA) immobilized Lactobacillus plantarum & Batch and continuous fermentation & $(45)$ \\
\hline Acid whey & Bacillus coagulans A534 & $\begin{array}{l}\text { Batch fermentation and continuous } \\
\text { fermentation }\end{array}$ & $(46)$ \\
\hline $\begin{array}{l}\text { Whey and yeast } \\
\text { extract }\end{array}$ & $\begin{array}{l}\text { Immobilized mixed culture of lactic acid bacteria (Lactobacillus } \\
\text { acidophilus LA-5, Bifidobacterium BB-12 and Streptococcus thermophiles) }\end{array}$ & $\begin{array}{l}\text { Batch fermentation in Erlenmeyer } \\
\text { flask }\end{array}$ & $(47)$ \\
\hline Whey permeate & $\begin{array}{l}\text { Co-culture of Lactobacillus delbrueckii and engineered Lactococcus } \\
\text { lactis }\end{array}$ & Batch fermentation & $(48)$ \\
\hline Cheese whey & $\begin{array}{l}\text { Mixed cultures } \\
\text { (the anaerobic digestate with inhibited methanogenic species) }\end{array}$ & $\begin{array}{l}\text { Dark fermentation; repeated-batch } \\
\text { mode aimed at semi-continuous lactic } \\
\text { acid production }\end{array}$ & $(49)$ \\
\hline
\end{tabular}

Table 2. Cheese whey application in production of biopolymers

\begin{tabular}{|c|c|c|c|}
\hline Substrate & Microorganism & Biopolymer & Ref. \\
\hline Cheese whey & $\begin{array}{l}\text { Lactobacillus sp. } \\
\text { Rhodovulum sulfidophilum DSM-1374 }\end{array}$ & Poly(3-hydroxybutyrate) & $(51)$ \\
\hline $\begin{array}{l}\text { Ricotta cheese } \\
\text { exhausted whey }\end{array}$ & $\begin{array}{l}\beta \text {-Galactosidase treatment and Haloferax mediterranei } \\
\text { DSM1411 }\end{array}$ & $\begin{array}{l}\text { Poly(3-hydroxybutyrate-co-3-hydroxyvalerate) (PHBV) } \\
\text { with hydroxyvalerate (HV) }\end{array}$ & $(52)$ \\
\hline $\begin{array}{l}\text { Fermented } \\
\text { cheese whey }\end{array}$ & $\begin{array}{l}\text { Mixed photosynthetic consortium of bacteria and } \\
\text { algae }\end{array}$ & PHA with a hydroxyvalerate (HV) & $(53)$ \\
\hline $\begin{array}{l}\text { Sweet whey } \\
\text { powder }\end{array}$ & $\begin{array}{l}\text { Mixed microbial culture (mostly Thauera and the } \\
\text { Lampropedia genera) }\end{array}$ & PHA & $(54)$ \\
\hline
\end{tabular}


properties comparable to polyethylene (PE) and polypropylene (PP) but are different in their biocompatibility, biodegradability by soil bacteria, UV-resistance and oxygen impermeability (56). The production costs are much higher than that of conventional plastics. Therefore, to commercialize PHAs, it is necessary to reduce the production cost through the development of efficient bacterial strains, more robust fermentation/recovery processes and find suitable and cheap substrates. Chen and Patel (57) reported that whey compounds are suitable for biological process taking place in PHA production, and they gave an excellent review covering this subject. In the last two decades, a noticeable number of studies have been made of PHA production from whey permeate using pure cultures of wild type microorganisms or recombinant ones. Three possible routes from whey lactose to PHA emerged: direct conversion of lactose to $\mathrm{PHA}$, conversion of glucose and galactose to PHA after the hydrolysis of lactose (chemically or enzymatically), and lactose fermentation to lactic acid followed by conversion of lactic acid to PHA. A limited number of microorganisms have the ability to directly convert lactose to PHAs (e.g. Hydrogenophaga pseudoflava and recombinant Escherichia coli, due to their $\beta$-galactosidase activity), so in several of these works, whey lactose was hydrolysed by lactase and used by microorganisms such as Pseudomonas hydrogenovora or Haloferax mediterranei to produce PHAs (58). The other way around, genetic information for PHA accumulation can be transferred from the acknowledged PHA-producers to easily cultivated non-PHA-producers, or PHA-producers can be genetically and metabolically modified to convert additional substrates to PHB to enhance conversion, optimise polyester composition, and increase productivity. Also, genetic engineering may increase the molar fraction of 3-hydroxyvalerate (3HV) in co-polyesters as demonstrated by Heinrich et al. (59).

\section{Polylactic acid}

Polylactic acid (PLA) is a biodegradable biopolyester made by condensation of lactic acid (LA) monomers, and one of the most promising environmentally friendly (green) plastics of the era, as it closely resembles polystyrene (PS) and polypropylene (PP) in most of its properties. Due to its low toxicity, PLA has a GRAS status (Generally Regarded as Safe) and can be also used in food packaging. It is biodegradable, so it can be composted in earthen trenches along with other biodegradable materials, such as plant and vegetable wastes and animal wastes, and its disposal will not cause any environmental concern (37). Despite its biodegradability, if improperly disposed in landfills, it will last for years like petrol plastics. PLA occurs in three different forms: poly(L-lactic acid) (PLLA), poly(D-lactic acid) (PDLA) and poly(DL-lactic acid) (PDLLA). Even though PLLA is suitable for industrial use, its application is limited by its low thermal stability (melting point $180^{\circ} \mathrm{C}$ ), unlike the stereocomplexes (SC) of PLLA and PDLA, which are heat stable (melting point $230^{\circ} \mathrm{C}$ ), resistant to hydrolysis, and have better mechanical properties (38). Production of PLA increased the demand for $D-L A$, so an eco-friendly microbial production of $\mathrm{D}$-LA came in focus. It can be produced by wild-type strains such as Sporolactobacillus laevolacticus, Lactobacillus plantarum, Sporolactobacillus ilulins and Lactobacillus bulgaricus (36). PLA is a good substitution for hydrocarbon-based polymers, but due to the high cost of D-LA fermentation, its production is not a competitive solution. Utilisation of renewable materials, primarily agro-industrial wastes such as whey and whey permeate is an auspicious alternative for the cost-reduced production of D-LA. Cellulac (60) was the first company worldwide to carry out a continuous industrial level production of lactic acid from deproteinised lactose whey. Their system used non-GMO (genetically modified organism) Lactobacillus (whole cells) to transform the lactose from deproteinised lactose whey into D-LA suitable for conversion to bioplastics. Prasad et al. (61) in their study demonstrated homo-lactic fermentative conversion of whey permeate by L. lactis to high value-added D-LA, as well as Liu et al. (38), who obtained a high D-LA titre and productivity by $L$. bulgaricus fermentation.

\section{Bioethanol}

Bioethanol has stood out as a potential alternative and environmentally friendly fuel for the future (green fuel). Since it does not produce any toxic emissions on combustion, bioethanol proves to be effective in decreasing air pollution and reducing global warming. Therefore, its production is empowered by legislative incentives all over the world. In 2007, more than $95 \%$ ethanol acquired in the USA was produced from corn, and the excess $5 \%$ came from wheat and barley or agro-industrial wastes (cheese whey and certain beverage remains) (62). To forestall the lack of food crops or rural assets, just as to mitigate the environmental impact of industrial and agricultural wastes, various strategies for bioethanol production have been developed based on implementing non-food agriculture crops and various agro-industrial wastes. Among these wastes, whey has stood out as a suitable substrate for bioethanol production due to its high organic load and high pollution potential. Although the conversion of the lactose and other whey constituents into bioethanol is barely competitive with the current technologies using sugarcane, corn starch or utilising lignocellulosic biomass as raw material, bioconversion of whey into ethanol draws attention. Direct fermentation of whey is not economically reasonable due to the low lactose content and low bioethanol yield (2-3\%), leading to high capital investments in the distillery. Better bioethanol yield may be achieved by fermenting whey with high lactose concentration, i.e. whey concentrated by ultrafiltration and/ or reverse osmosis. The conventional industrial strain of Saccharomyces cerevisiae lacks lactose breakdown enzymes, so lactose has to be enzymatically hydrolysed prior to the alcoholic fermentation by Saccharomyces cerevisiae (62). In contrast, Kluyveromyces marxianus strains have the ability to metabolize lactose and are commonly used yeast strains for the fermentation of lactose into bioethanol. Gabardo et al. (63) 
stated that continuous fermentation, when cells of $K$. marxianus are immobilised in calcium alginate, improves ethanol yield, achieving $6.97 \mathrm{~g} /(\mathrm{L} \cdot \mathrm{h})$ productivity. Sampaio et al. (64) investigated the ability of $K$. lactis to ferment cheese whey and obtained $15.0 \mathrm{~g} / \mathrm{L}$ ethanol, $0.47 \mathrm{~g} / \mathrm{g}$ yield on consumed lactose and $0.31 \mathrm{~g} /$ (L.h) productivity, corresponding to $87.4 \%$ fermentation efficiency. Since the introduction of modern approaches such as genetic engineering, the use of engineered S. cerevisiae for lactose fermentation has drawn much attention and attempts have been made to construct lactose-consuming S. cerevisiae strains. In the commercial production of bioethanol from whey permeate, K. marxianus var. marxianus and $K$. fragilis var. marxianus are commonly used (Table 3 ), and there are some examples of such industrial units in Ireland, New Zealand, Denmark and the USA (62). Bioethanol obtained from whey can be utilised in food, chemical, drug and cosmetic industries and as an alternative and sustainable fuel.

Table 3. Bioethanol production from cheese whey

$\begin{array}{lll}\text { Substrate } & \begin{array}{l}\text { Microorganism/enzyme } \\ \text { source }\end{array} & \text { Ref. } \\ \text { Crude whey } & \begin{array}{l}\text { Genetically engineered } \\ \text { S. cerevisiae strain }\end{array} & (65) \\ \text { Crude whey } & \text { K. marxianus ETP87 } & (66) \\ \text { Cheese whey permeate } & \text { K. lactis CBS2359 } & (64) \\ \text { Cheese whey } & \text { S. fragilis IZ 275 } & (67) \\ \text { Cheese whey powder } & \text { K. marxianus and S. cerevisiae } & (68) \\ \text { Whey permeate } & \text { K. marxianus URM 7404 } & (69) \\ \text { Cheese whey powder } & \text { E. coli } & \text { (70) } \\ \text { Delactosed whey permeate } & \text { C. glutamicum } & \text { (71) } \\ \text { Cheese whey powder } & \text { K. lactis } \beta \text {-galactosidase and } & \text { (72) } \\ \text { Mozzarella cheese whey } & \text { S. cerevisiae } & \\ \text { and sugarcane molasses } & \text { C. tropicalis and B. capitatus } & \text { (73) } \\ \text { Cheese whey permeate } & \text { K. marxianus NCIM 3217 } & \text { (74) } \\ \text { Whey permeate } & \text { L. lactis } & \text { (75) }\end{array}$

\section{Single cell proteins}

Production of single cell protein (SCP) is one of basic steps in solving the problem of increasing demands for innovative and alternative food sources. SCP is defined as a 'protein extracted from cultivated microbial biomass', referring to dehydrated cells of various microorganisms (algae, actinomycetes, bacteria, yeast, moulds and higher fungi) grown in large-scale culture systems for use as protein source in human food or animal feed. It can be used for protein supplementation as an alternative to expensive conventional sources such as soy meat and fish meat (6). Whey utilisation as a substrate for the production of SCP may reduce polluting potential of whey and result in the production of a value-added product. Whole whey or whey permeate is a convenient substrate for the SCP production via direct use of lactose by lactose-consuming microorganisms, or indirectly after the hydrolysis of lactose by enzymatic or chemical means for a microorganism that does not grow on lactose. The Kluyveromyces species have been most widely studied for SCP production from whey, in particular K. marxianus or K. fragilis strains, which are GRAS microorganisms and offer advantages of good growth yields (76). Sampaio et al. (77) suggested that cheese whey, adequately enriched with salts and yeast extract, could be interestingly exploited as an alternative medium for the production of K. lactis as a single cell protein. Nayeem et al. (78) also proposed whey as a suitable substrate for SCP production after the fermentation using strains of $K$. marxianus where the biomass yield of $36 \mathrm{mg} / \mathrm{mL}$ was obtained with $83.33 \%$ crude protein content. Not many studies have looked at SCP microalgae. Putri et al. (79) utilised cheese whey waste as a nitrogen source for the growth of Chlorella sp. as a unicellular producer with high growth rate, high protein content, high chlorophyll content and low nucleic acid content.

\section{Whey protein utilisation}

Whey proteins constitute about $20 \%$ of the total proteins present in the milk. They are a mix of globular proteins with a relatively even distribution of non-polar, polar and charged amino acids that can be isolated from whey and represent one of the nutritionally most valuable components of whey. They are composed mainly of $\beta$-lactoglobulin ( $\beta$-Lg), a-lactalbumin ( $a-L a)$, bovine serum albumin (BSA), immunoglobulin (Ig), thermostable proteose-peptones and lactoferrin (Lf) representing about $50,20-25,10-15,6,1$ and less than $1 \%$ of whey protein fractions respectively (8). Unlike caseins that exist as a micellar suspension, whey proteins have a compact globular structure with quite different amino acid profiles. Because of the smaller fraction of Glu and Pro and greater Cys/Met ratio, these proteins have a higher biological value and are more easily digested than other proteins of animal origin (13). They have been reported to possess a plethora of nutritional and biological benefits, which are mainly associated with the bioactive peptides that stem from proteolytic breakdown of whey proteins. Such bioactive peptides have an indispensable role in the dietary management of chronic diseases (cardiovascular, digestive, immune and nervous systems). The beneficial health effects of whey proteins can be classified as antimicrobial, antioxidative, antithrombotic, antihypertensive or immunomodulatory (80). The development of methods for protein separation, purification and drying (membrane separation and chromatography, electrodialysis, spray and freeze drying) have drawn the attention of the academic community towards the distinct biological and functional characteristics of whey proteins and widened their application (81). Besides food and beverages, whey proteins have other numerous praiseworthy applications in food industry, as they can be easily shaped into different bases and matrices (macro-, micro- and nanostructures) suitable for carrying several types of bioactive compounds, different flavours or compounds with high nutritional value. Also, there are several reports that indicate a targeted application of whey proteins as surface-active components, texture modifiers, foaming and gelling agents, thickening agents and emulsifiers (82-84). Recent developments in this field are 
focused on development of novel whey protein-based value-added products such as whey protein-based edible films, hydrogels, nanoparticles and microencapsulated products (81).

\section{Edible films and coatings}

The demand for so called 'green' packaging has accelerated research on active bio-based packaging. Edible or biodegradable films are green alternatives to traditional plastics and thus also help in controlling environmental pollution. These biofilms have plenty of advantages, as they may replace or reinforce existing natural layers, preserve moisture and prevent loss of important components (e.g. flavours) and above all, can be eaten together with the product without prior removal (85). Reuse and recycling of agro-industrial wastes have attracted significant scientific interest towards the exploitation of whey protein in order to create edible films and coatings (Table 4). Whey protein films with their admirable oxygen barrier properties stand out as sustainable biodegradable alternative materials to replace typically used nylon or polyester films. Moreover, whey proteins can form

Table 4. Whey-based edible films and coatings

\begin{tabular}{|c|c|c|c|}
\hline $\begin{array}{l}\text { Film forming } \\
\text { material }\end{array}$ & Plasticiser & Supplement & Ref. \\
\hline $\begin{array}{l}\text { WPI } \\
(5 \% \mathrm{~m} / \mathrm{V}) \\
\text { and water } \\
\text { soluble } \\
\text { derivative } \\
\text { of chitosan } \\
(3 \% \mathrm{~m} / \mathrm{V})\end{array}$ & $\begin{array}{l}\text { Glycerol } \\
(1.8 \% \mathrm{~m} / \mathrm{V})\end{array}$ & & (86) \\
\hline $\begin{array}{l}\text { WPI } \\
(W=8 \%)\end{array}$ & $\begin{array}{l}\text { Glycerol } \\
(w=26-54 \%)\end{array}$ & $\begin{array}{l}\text { Lemon and } \\
\text { bergamot } \\
\text { essential oils }\end{array}$ & (87) \\
\hline $\begin{array}{l}\text { WPC } \\
(w=10 \%), \\
\text { guar gum } \\
(w=0.7 \%)\end{array}$ & $\begin{array}{l}\text { Glycerol } \\
(w=5 \%)\end{array}$ & $\begin{array}{l}\text { L. buchneri } \\
\text { UTAD104, } \\
\text { L. casei UM3 } \\
(w=10,20 \text { or } 30 \%)\end{array}$ & (88) \\
\hline $\begin{array}{l}\text { WPI } \\
(5 \% \mathrm{~m} / \mathrm{V}) \text {, } \\
\text { wax and } \\
\text { antifoam }\end{array}$ & $\begin{array}{l}\text { Glycerol } \\
(2 \% \mathrm{~m} / \mathrm{V})\end{array}$ & $\begin{array}{l}\text { Nisin }(10.000 \mathrm{IU}) ; \\
\text { sodium benzoate } \\
\text { and potassium } \\
\text { sorbate }(4 \% \mathrm{~m} / \mathrm{V}) ; \\
\text { thyme, rosemary, } \\
\text { basil, pimento } \\
\text { and coriander } \\
\text { essential oils } \\
(4 \% \mathrm{~m} / \mathrm{V})\end{array}$ & (89) \\
\hline $\begin{array}{l}\text { WPI, } \\
\text { chitosan }\end{array}$ & Glycerol & & (90) \\
\hline $\begin{array}{l}\text { WPI } \\
(5 \% m / V)\end{array}$ & $\begin{array}{l}\text { Glycerol }(4 \% \mathrm{~m} / \mathrm{V}) \\
\text { Glycerol }(4 \% \mathrm{~m} / \mathrm{V}) \\
\text { and } \\
\text { trehalose }(3 \% \mathrm{~m} / \mathrm{V})\end{array}$ & & (91) \\
\hline Whey protein & $\begin{array}{l}\text { Water, glycerol, } \\
\text { natural rubber } \\
\text { latex }\end{array}$ & & (92) \\
\hline $\begin{array}{l}\text { WPI, natural latex } \\
\text { and albumin }\end{array}$ & Water & & (93) \\
\hline
\end{tabular}

$\mathrm{WPI}=$ whey protein isolate, $\mathrm{WPC}=$ whey protein concentrate clear films and coatings with improved mechanical and barrier properties compared to polysaccharide-based films and may provide surface sterility (94). Besides the improved barrier properties, such films and coating also biodegrade fast. However, to develop new eco-efficient food packaging products with improved resistance to moisture transfer and enhanced flexibility, whey proteins need to be blended with suitable plasticisers, such as sorbitol or glycerol (94).

Pereira et al. (95) proposed alternative biomaterials for potential uses in food applications in form of WPC nanocomposites activated with lycopene and montmorillonite nanoparticles. Qazanfarzadeh and Kadivar (96) reinforced WPI nanocomposite film properties with oat husk nanocellulose. Incorporation of biocompounds with natural antioxidant or antimicrobial activity into the whey protein isolate matrix has also become a field of research. A recent study by Boyacı et al. (97) describes the development of an antimicrobial film composed of whey proteins, beeswax, oleic acid and lysozyme for the protection of unpackaged food in households. Extended shelf life, as well as improved quality and safety control of the products, are among the main advantages reported using such complex films. Andrade et al. (98) investigated biodegradable whey protein-based films incorporated with ethanolic rosemary and thyme extracts, and developed an active film with $1 \%$ incorporated rosemary extract. The film presented antimicrobial activity against $L$. monocytogenes and S. aureus. Soukoulis et al. (99) examined the survivability of L. rhamnosus GG on WPC and several other biopolymers as a carrier. The use of whey proteins as a carrier (base or matrix) during incorporation of functional ingredients (such as good bacteria, probiotics and prebiotics) into novel value-added products could improve their survival rates or activity during storage and consumption.

\section{Hydrogels}

Hydrogels are defined as polymeric three-dimensional networks that can assimilate high amounts of water or biological fluids due to the presence of hydrophilic groups, such as $-\mathrm{OH},-\mathrm{CONH},-\mathrm{CONH}_{2}-$ and $-\mathrm{SO}_{3} \mathrm{H}(81)$. Because of their interesting capability of consolidating the qualities of a hydrogel system with a nanoparticle, hydrogel nanoparticles have been the centre of attention in recent examination of drug delivery systems (85). Besides forming biofilms, whey proteins can also form polymeric 3D networks like hydrogels (7). In recent years, whey protein nanostructured particles have also attracted much attention because of their specific functional attributes such as: surface activity, ability to form hydrogels, GRAS properties, easy preparation, relatively low cost, and effectively monitored size distribution. To formulate novel food products, it is important to comprehend the interactions between the whey proteins and biopolymers such as pectin, K-carrageenan, xanthan and basil seed gum $(100,101)$. As hydrogels have specific structural and sensory characteristics for targeted functional foods, when developing new products such as fermented dairy beverages, ice 
cream, confectionery and bakery products, researchers are increasingly turning to hydrogel applications (7). Nourbakhsh et al. (102) managed to apply WPHs for encapsulation of water-soluble nutraceuticals. Su et al. (103) employed whey proteins for microencapsulation by using high internal phase emulsions stabilized with WPI microgels to enhance the viability of Lactobacillus plantarum as probiotics. Fang et al. (104) used WPI nanoparticles for a-tocopherol and resveratrol encapsulation as protein-based carriers for hydrophobic components. When micro- and nanoparticles are used as carriers of bioactive compounds, the controlled release of incorporated bioactive compounds is enabled during consumption, which is crucial for improvement of nutritional and functional aspects of food. Defining the nanostructure of whey protein as a GRAS material allows their wider application in food research (105).

\section{ENVIRONMENTAL APPROACHES FOR WHEY UTILISATION}

Dairy sector has a heavy ecological footprint on the earth's ecosystems and public pressure forces the dairy industry to re-evaluate their whey management. Europe is the overall leader in dairy processing and subsequently the largest whey producer. The cheese industry produces about 115 million tonnes of whey annually and $47 \%$ of it is being directly disposed in the drains, causing serious environmental pollution problems (12). Owing to its high BOD and COD, whey is considered a major pollutant by-product worldwide. The contamination capability of whey has driven countries such as USA, Canada, Australia, New Zealand and the European Union to introduce strict environment protection legislation against inappropriate disposal of whey and in favour of its sustainable utilisation. In Europe, the landfill disposal of cheese whey has also been abolished due to the recently developed markets for whey proteins and regulatory requirements based upon the EU Landfill Directive 1999/31/EC (12). These strict legislations encouraged dairy industry to explore other approaches and opportunities for the management of dairy effluents. The reduction of dairy environmental impact is possible by following correctly sustainable procedures at all steps of the dairy supply chain, also focusing on waste reduction and virtuous use of by-products such as whey. Life cycle assessment (LCA) emerged as a generally accepted approach, implying an environmental study focusing on the complete life cycle of a product or a service, from resource extraction to end-of-life products considering all steps in between, by quantifying the environmental impact, such as climate change, ecosystem quality (i.e. aquatic acidification and eutrophication), human health and resources (energy and water) (106). LCA consists of four main phases: (i) defining the goal and scope of an LCA, (ii) analysis of the inventory necessary for carrying out the study, (iii) calculation and assessment of environmental impacts, and (iv) interpretation of the results (107). For the dairy sector, an LCA has to consider farm production (fodder, cow raising, milking or at farm refrigeration), packaging, dairy processing (processing for production of various dairy products), distribution (transports and retailers), use phase and end-of life (6).

The development of integrated biorefinery concept has drawn significant attention during the last years to reduce whey disposal by introducing holistic approaches of its valorisation to formulate a plethora of end-products (7). The use of all raw material flows in accordance with the concept of circular economy and zero waste generation, embracing all pillars of sustainability, i.e. the environment, society, and the economy, is one of the main premises of biorefineries (108). Therefore, new refining approaches have been proposed for conversion of dairy by-products into valuable bio-based products (e.g. additives, bioplastics or biochemicals), even into larger quantities of less-valuable products such as bioethanol, or smaller quantities of highly priced products such as nutraceuticals (109). Németh and Kaleta (11) set up a biorefinery concept for conversion of the lactose from whey into yeast biomass for ergosterol production (i.e. previtamin D2). After the ergosterol extraction, the residual yeast debris was combined with the lactic acid containing residual organic part of the whey and used in propionic acid and vitamin B12 production. Pasotti et al. (110) first reported efficient ethanol production from the lactose contained in whey permeate with engineered E. coli. Zhou et al. (72) first proposed two-step bioprocess using Saccharomyces cerevisiae and Gluconobacter oxydans to bioconvert cheese whey into ethanol and galactonic acid. Overall, a lot of effort has been invested into developing integral processes and setting up a closed food supply chain through the manufacture of novel food products. Reported studies regarding the biorefinery concept did not cover all aspects of cheese whey utilisation. Novel approaches, implementing both lactose and protein streams, will yield alternative bio-based components resulting in high value-added products with enhanced physicochemical, sensory and nutritional properties.

\section{CONCLUSIONS}

Environmental issues have forced governments to legislate the disposal of whey, and as a consequence encouraged dairy industry to explore other approaches and opportunities for the management of dairy wastes. Due to its high polluting capacity, reuse and recycling of whey has become a great scientific challenge in order to reduce dairy wastes and meet the Agenda 2030 sustainable development goals (SDG). These scientific efforts resulted in developing different sustainable methods for dealing with the whey and changed the attitude towards whey from cheesemaking waste to value-added raw material. These methods also contributed to the fulfilment of the Agenda 2030 6th SDG: clean water and sanitation, 9th SDG: industry, innovation and infrastructure, and 12th SDG: responsible consumption and production. Whey components make whey a great base for the creation of a series of new products or an ideal alternative compound to more traditional ones. The review highlights possibilities 
of utilisation of whey and its components, considering new refining approaches to convert dairy by-products into several valuable bio-based products. Large volumes of whey still need to be processed, so more efficient and economic integrated processes and systems must be developed, especially in the emerging fields of biochemicals, biofuels and bioplastics.

\section{FUNDING}

The paper was produced as part of the project 'Modification of cheese ripening process and whey product development - SIRENA' (KK.01.1.1.04.0096) and 'Atrium of Knowledge' (KK.01.1.1.02.0005) co-financed by the European Union from the European Regional Development Fund and the Operational Programme Competitiveness and Cohesion 2014-2020.

\section{CONFLICT OF INTEREST}

The authors declare that there is no conflict of interest.

\section{AUTHORS CONTRIBUTION}

A. Režek Jambrak gave the idea for the article. E. Zandona performed literature search and data analysis. E. Zandona and M. Blažić drafted the paper. A. Režek Jambrak and M. Blažić critically revised the work.

\section{ORCID ID}

E. Zandona (ํ) https://orcid.org/0000-0002-5131-8081

M. Blažić @ i https://orcid.org/0000-0001-5649-2583

A. Režek Jambrak @i http://orcid.org/0000-0001-7676-6465

\section{REFERENCES}

1. Chatzipaschali AA, Stamatis AG. Biotechnological utilization with a focus on anaerobic treatment of cheese whey: Current status and prospects. Energies. 2012;5(9):3492-525. https://doi.org/10.3390/en5093492

2. Macwan SR, Dabhi BK, Parmar SC, Aparnathi KD. Whey and its utilization. Int J Curr Microbiol Appl Sci. 2016;5(8):134-55. https://doi.org/10.20546/ijcmas.2016.508.016

3. UN General Assembly. Transforming our world: the 2030 Agenda for Sustainable Development. New York, USA: United Nations; 2015. Available from: https://sdgs.un.org/ sites/default/files/publications/21252030\%20Agenda\%20 for\%20Sustainable\%20Development\%20web.pdf.

4. Valta K, Damala P, Angeli E, Antonopoulou G, Malamis D, Haralambous KJ. Current treatment technologies of cheese whey and wastewater by Greek cheese manufacturing units and potential valorisation opportunities. Waste Biomass Valori. 2017;8:1649-63.

https://doi.org/10.1007/s12649-017-9862-8

5. Panghal A, Patidar R, Jaglan S, Chhikara N, Khatkar SK, Gat $Y$, Sindhu N. Whey valorization: Current options and future scenario: A critical review. Nutr Food Sci. 2018;48(3):520-35. https://doi.org/10.1108/NFS-01-2018-0017

6. Çelik K, Önür ZY, editors. Whey every aspect. Istanbul, Turkey: Tudás Alapítvány; 2016. Available from: http://www. whey-europe.eu/pluginfile.php/177/mod_forum/attachment/15/5-Q5b-Training\%20Handbook-\%20Whey\%20 Every\%20Aspect.pdf.

7. Lappa IK, Papadaki A, Kachrimanidou V, Terpou A, Koulougliotis D, Eriotou E, Kopsahelis N. Cheese whey processing: Integrated biorefinery concepts and emerging food applications. Foods. 2019;8(8):347.

https://doi.org/10.3390/foods8080347

8. Blažić M, Zavadlav S, Kralj E, Šarić G. Production of whey protein as nutritional valuable foods. Croat J Food Sci Technol. 2018;10(2):255-60.

https://doi.org/10.17508/CJFST.2018.10.2.09

9. Fox PF, Guinee TP, Cogan TM, McSweeney PLH. Whey and whey products. In: Fox PF, Guinee TP, Cogan TM, McSweeney PLH, editors. Fundamentals of cheese science. Boston, MA, USA: Springer; 2017. pp. 755-69.

https://doi.org/10.1007/978-1-4899-7681-9_22

10. Gregurek Lj. Cheesemaking - Theory and practice. Zagreb, Croatia: PROBIOTIK d.o.o.; 2015 (in Croatian).

11. Németh Á, Kaleta Z. Complex utilization of dairy waste (whey) in biorefinery. WSEAS Trans Environ Dev. 2015;11:80-8.

12. Papademas $P$, Kotsaki P. Technological utilization of whey towards sustainable exploitation. J Adv Dairy Res. 2019;7(4): 231.

https://doi.org/10.35248/2329-888X.19.7.231

13. Božanić R, Barukčić I, Lisak K. Possibilities of whey utilisation. Austin J Nutr Food Sci. 2014;2(7):7.

14. Barukčić I, Jakopović KL, Božanić R. Whey and buttermilk: Neglected sources of valuable beverages. In: Mihai Grumezescu A, Holban AM, editors. In: Natural beverages. Cambridge, MA, USA: Academic Press; 2019. pp. 209-42. https://doi.org/10.1016/B978-0-12-816689-5.00008-0

15. Amaral GV, Silva EK, Cavalcanti RN, Martins CPC, Andrade LGZS, Moraes J, et al. Whey-grape juice drink processed by supercritical carbon dioxide technology: Physicochemical characteristics, bioactive compounds and volatile profile. Food Chem. 2018;239:697-703.

https://doi.org/10.1016/j.foodchem.2017.07.003

16. Režek Jambrak A, Vukušić T, Donsi F, Paniwnyk L, Djekic I. Three pillars of novel nonthermal food technologies: food safety, quality, and environment. J Food Qual. 2018;2018:Article ID 8619707.

https://doi.org/10.1155/2018/8619707

17. Barukčić I, Božanić R, Kulozik U. Influence of process temperature and microfiltration pre-treatment on flux and fouling intensity during cross-flow ultrafiltration of sweet whey using ceramic membranes. Int Dairy J. 2015;51:1-7. https://doi.org/10.1016/j.idairyj.2015.07.002 
18. Barukčić I, Lisak Jakopović K, Herceg Z, Karlović S, Božanić R. Influence of high intensity ultrasound on microbial reduction, physico-chemical characteristics and fermentation of sweet whey. Innov Food Sci Emerg Technol. 2015; 27:94-101.

https://doi.org/10.1016/j.ifset.2014.10.013

19. Antonelli J, Lindino C A, de Azevedo JCR, de Souza SNM, Cremonez PA, Rossi E. Biogas production by the anaerobic digestion of whey. Rev Cienc Agric. 2016;39(3):463-7.

https://doi.org/10.19084/RCA15087

20. Hosseini SE, Wahid MA. Hydrogen production from renewable and sustainable energy resources: promising green energy carrier for clean development. Renew Sustain Energy Rev. 2016;57:850-66.

https://doi.org/10.1016/j.rser.2015.12.112

21. Gadhe A, Sonawane SS, Varma MN. Enhanced biohydrogen production from dark fermentation of complex dairy wastewater by sonolysis. Int J Hydrogen Energ. 2015;40(32): 9942-51.

https://doi.org/10.1016/j.ijhydene.2015.06.098

22. Rosa PRF, Santos SC, Silva EL. Different ratios of carbon sources in the fermentation of cheese whey and glucose as substrates for hydrogen and ethanol production in continuous reactors. Int J Hydrogen Energ. 2014;39:1288-96. https://doi.org/10.1016/j.ijhydene.2013.11.011

23. Lima DMF, Lazaro CZ, Rodrigues JAD, Ratusznei SM, Zaiat M. Optimization performance of an AnSBBR applied to biohydrogen production treating whey. J Environ Manage. 2016;169:191-201.

https://doi.org/10.1016/j.jenvman.2015.12.032

24. Rivera I, Bakonyi P, Cuautle-Marín MA, Buitrón G. Evaluation of various cheese whey treatment scenarios in single-chamber microbial electrolysis cells for improved biohydrogen production. Chemosphere. 2017;174:253-9.

https://doi.org/10.1016/j.chemosphere.2017.01.128

25. Blanco VMC, Oliveira GHD, Zaiat M. Dark fermentative biohydrogen production from synthetic cheese whey in an anaerobic structured-bed reactor: Performance evaluation and kinetic modeling. Renew Energ. 2019;139:1310-9.

https://doi.org/10.1016/j.renene.2019.03.029

26. Kwak HS, Lee WJ, Lee MR. Revisiting lactose as an enhancer of calcium absorption. Int Dairy J. 2012;22(2):147-51.

https://doi.org/10.1016/j.idairyj.2011.09.002

27. Francavilla R, Calasso M, Calace L, Siragusa S, Ndagijimana $M$, Vernocchi, $P$, et al. Effect of lactose on gut microbiota and metabolome of infants with cow's milk allergy. Pediatr Allergy Immunol. 2012;23(5):420-7. https://doi.org/10.1111/j.1399-3038.2012.01286.x

28. Musci I. Nutrients in whey and nutritional properties of whey products. In: Celik K, Önur, ZY, editors. Whey every aspect. Istanbul, Turkey: Tudás Alapítvány; 2016. pp. 70-91.
29. Simone E, Tyler Al, Kuah D, Bao X, Ries ME, Baker D. Optimal design of crystallization processes for the recovery of a slow-nucleating sugar with a complex chemical equilibrium in aqueous solution: The case of lactose. Org Process Res Dev. 2019;23(2):220-33.

https://doi.org/10.1021/acs.oprd.8b00323

30. Das M, Raychaudhuri A, Ghosh SK. Supply chain of bioethanol production from whey: A review. Procedia Environ Sci. 2016;35:833-46.

31. Çelik K, Önür ZY, Baytekin H, Coşkun B. Whey processing: Utilization and major products. In: Celik K, Önur, ZY, editors. Whey every aspect. Istanbul, Turkey: Tudás Alapítvány; 2016. pp. 34-61.

32. WHO food additives series 29: Specifications for the identity and purity of food additives and their toxicological evaluation: some flavouring substances and non-nutritive sweetening agents. Eleventh report of the Joint FAO/WHO Expert Committee on Food Additives (JECFA). Geneva, Switzerland: World Health Organization \& Food and Agriculture Organization of the United Nations. (FAO/WHO); 1967. Available from: https://apps.who.int/iris/handle/ 10665/40684.

33. Pleissner D, Dietz D, van Duuren JBJH, Wittmann C, Yang X, Lin CSK, Venus J. Biotechnological production of organic acids from renewable resources. In: Wagemann K, Tippkötter $\mathrm{N}$, editors. Biorefineries. Advances in biochemical engineering/biotechnology, vol. 166. Cham, Switzerland: Springer; 2017. pp 373-410.

https://doi.org/10.1007/10_2016_73

34. Idler C, Venus J, Kamm B. Microorganisms for the production of lactic acid and organic lactates. In: Kamm B, editor. Microorganisms in biorefineries. Microbiology Monographs, vol. 26. Berlin, Heidelberg: Springer; 2015. pp. 22573.

https://doi.org/10.1007/978-3-662-45209-7_9

35. Juturu V, Wu JC. Microbial production of lactic acid: The latest development. CRC Crit Rev Biotechnol. 2016;36:967-77. https://doi.org/10.3109/07388551.2015.1066305

36. Awasthi D, Wang L, Rhee MS, Wang Q, Chauliac D, Ingram LO, Shanmugam KT. Metabolic engineering of Bacillus subtilis for production of D-lactic acid. Biotechnol Bioeng. 2018; 115(2):453-63.

https://doi.org/10.1002/bit.26472

37. Narayanan CM, Das S, Pandey A. Food waste utilization: Green technologies for manufacture of valuable products from food wastes and agricultural wastes. In: Grumezescu AM, Holban AM, editors. Food bioconversion. London, UK: Academic Press; 2017. pp. 1-54.

https://doi.org/10.1016/B978-0-12-811413-1.00001-2

38. Liu P, Zheng Z, Xu Q, Qian Z, Liu J, Ouyang J. Valorization of dairy waste for enhanced $D$-lactic acid production at low cost. Process Biochem. 2018;71:18-22.

https://doi.org/10.1016/j.procbio.2018.05.014 
39. Liang S, McDonald AG, Coats ER. Lactic acid production from potato peel waste by anaerobic sequencing batch fermentation using undefined mixed culture. Waste Managem. 2015;45:51-6.

https://doi.org/10.1016/j.wasman.2015.02.004

40. Uçkun Kıran E, Trzcinski AP, Liu Y. Platform chemical production from food wastes using a biorefinery concept. J Chem Technol Biotechnol. 2015;90(8):1364-79. https://doi.org/10.1002/jctb.4551

41. Zhang Y, Vadlani PV. Lactic acid production from biomass-derived sugars via co-fermentation of Lactobacillus brevis and Lactobacillus plantarum. J Biosci Bioeng. 2015; 119(6):694-9.

https://doi.org/10.1016/j.jbiosc.2014.10.027

42. Sahoo TK, Jayaraman G. Co-culture of Lactobacillus delbrueckii and engineered Lactococcus lactis enhances stoichiometric yield of D-lactic acid from whey permeate. Appl Microbiol Biotechnol. 2019;103(14):5653-62. https://doi.org/10.1007/s00253-019-09819-7

43. Mimitsuka T, Sawai K, Kobayashi K, Tsukada T, Takeuchi N, Yamada $\mathrm{K}$, et al. Production of D-lactic acid in a continuous membrane integrated fermentation reactor by genetically modified Saccharomyces cerevisiae: enhancement in D-lactic acid carbon yield. J Biosci Bioeng. 2015;119(1):65-71. https://doi.org/10.1016/j.jbiosc.2014.06.002

44. Catone MV, Palomino MM, Legisa DM, Martin JF, García VM, Ruzal SM, Allievi MC. Lactic acid production using cheese whey based medium in a stirred tank reactor by a cсpA mutant of Lacticaseibacillus casei. World J Microb Biotechnol. 2021;37(4):61. https://doi.org/10.1007/s11274-021-03028-z

45. Nagarajan D, Nandini A, Dong CD, Lee DJ, Chang JS. Lactic acid production from renewable feedstocks using poly(vinyl alcohol)-immobilized Lactobacillus plantarum 23. Ind Eng Chem Res. 2020;59(39):17156-64.

https://doi.org/10.1021/acs.iecr.0c01422

46. Olszewska-Widdrat A, Alexandri M, López-Gómez JP, Schneider $\mathrm{R}$, Venus J. Batch and continuous lactic acid fermentation based on a multi-substrate approach. Microorganisms. 2020;8(7):1084.

https://doi.org/10.3390/microorganisms8071084

47. Pinho CLC, Oliveira CES, Coimbra JC, Cotrim WDS. Production of lactic acid in a medium based on food industry effluents using an immobilized mixed dairy culture. Braz J Food Technol. 2019;22:2018100 (in Portuguese). https://doi.org/10.1590/1981-6723.10018

48. Sahoo TK, Jayaraman G. Co-culture of Lactobacillus delbrueckii and engineered Lactococcus lactis enhances stoichiometric yield of D-lactic acid from whey permeate. Appl Microbiol Biotechnol. 2019;103(14):5653-62.

https://doi.org/10.1007/s00253-019-09819-7
49. Luongo V, Policastro G, Ghimire A, Pirozzi F, Fabbricino M. Repeated-batch fermentation of cheese whey for semicontinuous lactic acid production using mixed cultures at uncontrolled pH. Sustainability. 2019;11(12):3330.

https://doi.org/10.3390/su11123330

50. Ziadi M, M'Hir S, Aydi A, Hamdi M. Bioreactor scale-up and kinetic modeling of lactic acid and biomass production by Enterococcus faecalis SLT13 during batch culture on hydrolyzed cheese whey. J Chem. 2020;2020:Article ID 1236784. https://doi.org/10.1155/2020/1236784

51. Carlozzi P, Giovannelli A, Traversi ML, Touloupakis E. Poly(3-hydroxybutyrate) bioproduction in a two-step sequential process using wastewater. J Water Process Eng. 2021;39:101700.

https://doi.org/10.1016/j.jwpe.2020.101700

52. Raho S, Carofiglio VE, Montemurro M, Miceli V, Centrone D, Stufano $\mathrm{P}$, et al. Production of the polyhydroxyalkanoate PHBV from ricotta cheese exhausted whey by Haloferax mediterranei fermentation. Foods. 2020;9(10):1459.

https://doi.org/10.3390/foods9101459

53. Fradinho JC, Oehmen A, Reis MAM. Improving polyhydroxyalkanoates production in phototrophic mixed cultures by optimizing accumulator reactor operating conditions. Int J Biol Macromol. 2019;126:1085-92.

https://doi.org/10.1016/j.ijbiomac.2018.12.270

54. Oliveira CS, Silva MO, Silva CE, Carvalho G, Reis MA. Assessment of protein-rich cheese whey waste stream as a nutrients source for low-cost mixed microbial PHA production. Appl Sci. 2018;8(10):1817.

https://doi.org/10.3390/app8101817

55. Ryan MP, Walsh G. The biotechnological potential of whey. Rev Environ Sci Biotechnol. 2016;15(3):479-98. https://doi.org/10.1007/s11157-016-9402-1

56. Anjum A, Zuber M, Zia KM, Noreen A, Anjum MN, Tabasum S. Microbial production of polyhydroxyalkanoates (PHAs) and its copolymers: A review of recent advancements. Int J Biol Macromol. 2016;89:161-74.

https://doi.org/10.1016/j.ijbiomac.2016.04.069

57. Chen GQ, Patel MK. Plastics derived from biological sources-present and future: A technical and environmental review. Chem Rev. 2012;112(4):2082-99.

https://doi.org/10.1021/cr200162d

58. Koller M, Maršálek L, de Sousa Dias MM, Braunegg G. Producing microbial polyhydroxyalkanoate (PHA) biopolyesters in a sustainable manner. New Biotechnol. 2017;37: 248.

https://doi.org/10.1016/j.nbt.2016.05.001

59. Heinrich D, Raberg M, Steinbüchel A. Synthesis of poly(3-hydroxybutyrate-co-3-hydroxyvalerate) from unrelated carbon sources in engineered Rhodospirillum rubrum. FEMS Microbiol Lett. 2015;362(8).

https://doi.org/10.1093/femsle/fnv038 
60. Lactic acid from lactose whey in worlds first continuous production runs. Cambridge, UK: Cellulac; 2014. Available from: http://cellulac.com/sf/lactic-acid-from-lactose-wheyin-world-first-continuous-production-runs/.

61. Prasad S, Srikanth K, Limaye AM, Sivaprakasam S. Homo-fermentative production of D-lactic acid by Lactobacillus sp. employing casein whey permeate as a raw feedstock. Biotechnol Lett. 2014;36:1303-7.

https://doi.org/10.1007/s10529-014-1482-9

62. Sharma D, Manzoor M, Yadav P, Sohal JS, Aseri GK, Khare N. Bio-valorization of dairy whey for bioethanol by stress-tolerant yeast. In: Gehlot P, Singh J, editors. Fungi and their role in sustainable development: Current perspectives. Singapore: Springer; 2018. pp. 349-66.

https://doi.org/10.1007/978-981-13-0393-7_20

63. Gabardo S, Rech R, Rosa CA, Ayub MAZ. Dynamics of ethanol production from whey and whey permeate by immobilized strains of Kluyveromyces marxianus in batch and continuous bioreactors. Renew Energ. 2014;69:89-96.

https://doi.org/10.1016/j.renene.2014.03.023

64. Sampaio FC, de Faria JT, da Silva MF, de Souza Oliveira RP, Converti A. Cheese whey permeate fermentation by Kluyveromyces lactis: A combined approach to wastewater treatment and bioethanol production. Environ Technol. 2020; 41:3210-8.

https://doi.org/10.1080/09593330.2019.1604813

65. Beniwal A, Saini P, De S, Vij S. Harnessing the nutritional potential of concentrated whey for enhanced galactose flux in fermentative yeast. LWT - Food Sci Technol. 2021;141: 110840.

https://doi.org/10.1016/j.lwt.2020.110840

66. Tesfaw A, Oner ET, Assefa F. Evaluating crude whey for bioethanol production using non-Saccharomyces yeast, Kluyveromyces marxianus. SN Appl Sci. 2021;3(1):42.

https://doi.org/10.1007/s42452-020-03996-1

67. Alves ÉdP, Morioka LRI, Suguimoto HH. Comparison of bioethanol and beta-galactosidase production by Kluyveromyces and Saccharomyces strains grown in cheese whey. Int J Dairy Technol. 2019;72:409-15.

https://doi.org/10.1111/1471-0307.12588

68. Farkas C, Rezessy-Szabó MJ, Gupta KV, Bujna E, Pham MT, Pásztor-Huszár K, et al. Batch and fed-batch ethanol fermentation of cheese-whey powder with mixed cultures of different yeasts. Energies. 2019;12:4495.

https://doi.org/10.3390/en12234495

69. Murari CS, da Silva DCMN, Schuina GL, Mosinahti EF, Del Bianchi VL. Bioethanol production from dairy industrial coproducts. Bioenerg Res. 2019;12:112-22.

https://doi.org/10.1007/s12155-018-9949-5

70. Sar T, Stark BC, Akbas MY. Bioethanol production from whey powder by immobilized E. coli expressing Vitreoscilla hemoglobin: Optimization of sugar concentration and in- oculum size. Biofuels. 2019;1-6.

https://doi.org/10.1080/17597269.2019.1583716

71. Shen J, Chen J, Jensen PR, Solem C. Development of a novel, robust and cost-efficient process for valorizing dairy waste exemplified by ethanol production. Microb Cell Fact. 2019;18(1):51.

https://doi.org/10.1186/s12934-019-1091-3

72. Zhou X, Hua X, Huang L, Xu Y. Bio-utilization of cheese manufacturing wastes (cheese whey powder) for bioethanol and specific product (galactonic acid) production via a two-step bioprocess. Bioresour Technol. 2019; 272:70-6. https://doi.org/10.1016/j.biortech.2018.10.001

73. Balia RL, Kurnani TBA, Utama GL. The combination of mozzarella cheese whey and sugarcane molasses in the production of bioethanol with the inoculation of indigenous yeasts. J Japan Inst Energ. 2018;97(9):266-9.

https://doi.org/10.3775/jie.97.266

74. Das B, Sarkar S, Maiti S, Bhattacharjee S. Studies on production of ethanol from cheese whey using Kluyveromyces marxianus. Materials Today: Proceedings. 2016;3(10):32537.

https://doi.org/10.1016/j.matpr.2016.10.006

75. Liu J, Dantoft SH, Würtz A, Jensen PR, Solem C. A novel cell factory for efficient production of ethanol from dairy waste. Biotechnol Biofuels. 2016;9(1):33.

https://doi.org/10.1186/s13068-016-0448-7

76. Yadav JSS, Yan S, Ajila CM, Bezawada J, Tyagi RD, Surampalli RY. Food-grade single-cell protein production, characterization and ultrafiltration recovery of residual fermented whey proteins from whey. Food Bioprod Process. 2016;99: 156-65.

https://doi.org/10.1016/j.fbp.2016.04.012

77. Sampaio FC, da Conceição Saraiva TL, e Silva GDDL, de Faria JT, Pitangui CG, Aliakbarian B, et al. Batch growth of Kluyveromyces lactis cells from deproteinized whey: Response surface methodology versus artificial neural network - Genetic algorithm approach. Biochem Eng J. 2016; 109:305-11.

https://doi.org/10.1016/j.bej.2016.01.026

78. Nayeem M, Chauhan K, Khan S, Rattu G, Dhaka RK, Sidduqui $\mathrm{H}$. Optimization of low-cost substrate for the production of single cell protein using Kluyveromyces marxianus. Pharma Innov J. 2017;6(8):22-5.

79. Putri D, Ulhidayati A, Musthofa I, Wardani A. Single cell protein production of Chlorella sp. using food processing waste as a cultivation medium. IOP Conf Ser: Earth Environ Sci. 2018;131:012052.

https://doi.org/10.1088/1755-1315/131/1/012052

80. Brandelli A, Daroit DJ, Folmer Correa AP. Whey as a source of peptides with remarkable biological activities. Food Res Int. 2015;73:149-61.

https://doi.org/10.1016/j.foodres.2015.01.016 
81. Khaire RA, Gogate PR. Whey proteins. In Galanakis CM, editor. Proteins: sustainable source, processing and applications. Cambridge, MA, USA: Academic Press; 2019. pp. 193 223.

https://doi.org/10.1016/B978-0-12-816695-6.00007-6

82. Fu W, Nakamura T. Explaining the texture properties of whey protein isolate/starch co-gels from fracture structures. Biosci Biotechnol Biochem. 2017;81:839-47. https://doi.org/10.1080/09168451.2017.1282812

83. Khalifa I, Nie R, Ge Z, Li K, Li C. Understanding the shielding effects of whey protein on mulberry anthocyanins: Insights from multispectral and molecular modelling investigations. Int J Biol Macromol. 2018;119:116-24.

https://doi.org/10.1016/j.ijbiomac.2018.07.117

84. Andoyo R, Dianti Lestari V, Mardawati E, Nurhadi B. Fractal dimension analysis of texture formation of whey protein-based foods. Int J Food Sci. 2018;2018:7673259.

https://doi.org/10.1155/2018/7673259

85. de Castro RJS, Domingues MAF, Ohara A, Okuro PK, dos Santos JG, Brexó RP, Sato HH. Whey protein as a key component in food systems: physicochemical properties, production technologies and applications. Food Struct. 2017;14:17-29.

https://doi.org/10.1016/j.foostr.2017.05.004

86. Braber NLV, Di Giorgio L, Aminahuel CA, Vergara LID, Costa AOM, Montenegro MA, Mauri AN. Antifungal whey protein films activated with low quantities of water soluble chitosan. Food Hydrocolloids. 2021;110:106156.

https://doi.org/10.1016/j.foodhyd.2020.106156

87. Çakmak H, Özselek Y, Turan OY, Fıratlıgil E, KarbancioğluGüler F. Whey protein isolate edible films incorporated with essential oils: antimicrobial activity and barrier properties. Polym Degrad Stabil. 2020;179:109285.

https://doi.org/10.1016/j.polymdegradstab.2020.109285

88. Guimarães AC, Ramos Ó, Cerqueira M, Venâncio A, Abrunhosa L. Active whey protein edible films and coatings incorporating Lactobacillus buchneri for Penicillium nordicum control in cheese. Food Bioprocess Technol. 2020;13:107486.

\section{https://doi.org/10.1007/s11947-020-02465-2}

89. Kalkan S, Erginkaya Z. Impact of whey protein isolate coatings containing different antimicrobial agents on sliced bologna-type sausage during refrigerated storage. Food Sci Tech. 2020;40:136-5.

https://doi.org/10.1590/fst.05119

90. Muley AB, Singhal RS. Extension of postharvest shelf life of strawberries (Fragaria ananassa) using a coating of chitosan-whey protein isolate conjugate. Food Chem. 2020; 329:127213.

https://doi.org/10.1016/j.foodchem.2020.127213

91. Feng Z, Wu G, Liu C, Li D, Jiang B, Zhang X. Edible coating based on whey protein isolate nanofibrils for antioxidation and inhibition of product browning. Food Hydrocolloid. 2018;79:179-88.

https://doi.org/10.1016/j.foodhyd.2017.12.028

92. Jones A, Mandal A, Sharma S. Protein-based bioplastics and their antibacterial potential. J Appl Polym Sci. 2015; 132(18):41931.

https://doi.org/10.1002/app.41931

93. Sharma S, Luzinov I. Whey based binary bioplastics. J Food Eng. 2013;119(3):404-10.

https://doi.org/10.1016/j.jfoodeng.2013.06.007

94. Basiak E, Lenart A, Debeaufort F. Effects of carbohydrate/ protein ratio on the microstructure and the barrier and sorption properties of wheat starch-whey protein blend edible films. J Sci Food Agric. 2017;97(3):858-67.

https://doi.org/10.1002/jsfa.7807

95. Pereira RC, Carneiro JDS, Assis OB, Borges SV. Mechanical and structural characterization of whey protein concentrate/montmorillonite/lycopene films. J Sci Food Agric. 2017;97:4978-86.

https://doi.org/10.1002/jsfa.8376

96. Qazanfarzadeh Z, Kadivar M. Properties of whey protein isolate nanocomposite films reinforced with nanocellulose isolated from oat husk. Int J Biol Macromol. 2016; 91:1134-40.

https://doi.org/10.1016/j.jjbiomac.2016.06.077

97. Boyacı D, Korel F, Boyacı, D, Korel F, Yemenicioğlu A. Development of activate-at-home-type edible antimicrobial films: an example $\mathrm{pH}$-triggering mechanism formed for smoked salmon slices using lysozyme in whey protein films. Food Hydrocolloid. 2016;60:170-8.

https://doi.org/10.1016/j.foodhyd.2016.03.032

98. Andrade MA, Ribeiro-Santos R, Costa Bonito MC, Saraiva $M$, Sanches-Silva A. Characterization of rosemary and thyme extracts for incorporation into a whey protein based film. LWT - Food Sci Technol. 2018;92:497-508.

https://doi.org/10.1016/j.Iwt.2018.02.041

99. Soukoulis C, Behboudi-Jobbehdar S, Macnaughtan W, Parmenter C, Fisk ID. Stability of Lactobacillus rhamnosus GG incorporated in edible films: Impact of anionic biopolymers and whey protein concentrate. Food Hydrocolloid. 2017;70:345-55.

https://doi.org/10.1016/j.foodhyd.2017.04.014

100. Sogut E, Ili Balqis AM, Nur Hanani ZA, Seydim AC. The properties of $\mathrm{K}$-carrageenan and whey protein isolate blended films containing pomegranate seed oil. Polym Test. 2019;77:105886.

https://doi.org/10.1016/j.polymertesting.2019.05.002

101. Protte K, Weiss J, Hinrichs J, Knaapila A. Thermally stabilised whey protein-pectin complexes modulate the thermodynamic incompatibility in hydrocolloid matrixes: A feasibility-study on sensory and rheological 
characteristics in dairy desserts. LWT - Food Sci Technol. 2019;105: 336-43.

https://doi.org/10.1016/j.lwt.2019.01.047

102. Nourbakhsh H, Madadlou A, Emam-Djomeh Z, Wang YC, Gunasekaran S, Mousavi ME. One-pot procedure for recovery of gallic acid from wastewater and encapsulation within protein particles. J Agric Food Chem. 2016;64(7): 1575-82.

https://doi.org/10.1021/acs.jafc.5b04867

103. Su J, Wang X, Li W, Chen L, Zeng X, Huang Q, Hu B. Enhancing the viability of Lactobacillus plantarum as probiotics through encapsulation with high internal phase emulsions stabilized with whey protein isolate microgels. J Agric Food Chem. 2018;66(46):12335-43.

https://doi.org/10.1021/acs.jafc.8b03807

104. Fang Z, Bao H, Ni Y, Choijilsuren N, Liang L. Partition and digestive stability of a-tocopherol and resveratrol/naringenin in whey protein isolate emulsions. Int Dairy J. 2019; 93:116-23.

https://doi.org/10.1016/j.idairyj.2019.01.017

105. Ramos OL, Pereira RN, Martins A, Rodrigues R, Fuciños C, Teixeira JA, et al. Design of whey protein nanostructures for incorporation and release of nutraceutical compounds in food. Crit Rev Food Sci Nutr. 2017;57(7):137793.

https://doi.org/10.1080/10408398.2014.993749
106. Djekic I, Pojić M, Tonda A, Putnik P, Bursać Kovačević D, Režek-Jambrak A, Tomasevic I. Scientific challenges in performing life-cycle assessment in the food supply chain. Foods. 2019;8(8):301.

https://doi.org/10.3390/foods8080301

107. ISO 14040:2006. Environmental management - Life cycle assessment - principles and framework. Geneva, Switzerland: International Organization for Standardization (ISO); 2006.

108. Romaní A, Michelin M, Domingues L, Teixeira JA. Valorization of wastes from agrofood and pulp and paper industries within the biorefinery concept: southwestern Europe scenario. In: Bhaskar T, Pandey A, Mohan SV, Lee DJ, Khanal SK, editors. Waste biorefinery. Potential and perspectives. Amsterdam, The Netherlands: Elsevier Inc; 2018. pp. 487-504. https://doi.org/10.1016/B978-0-444-63992-9.00016-1

109. Popa VI. Biomass for fuels and biomaterials. In: Popa V, Volf I, editors. Biomass as renewable raw material to obtain bioproducts of high-tech value. Amsterdam, The Netherlands: Elsevier Inc; 2018. pp. 1-37. https://doi.org/10.1016/B978-0-444-63774-1.00001-6

110. Pasotti L, Zucca S, Casanova M, Micoli G, Cusella De Angelis MG, Magni P. Fermentation of lactose to ethanol in cheese whey permeate and concentrated permeate by engineered Escherichia coli. BMC Biotechnol. 2017;17:48. https://doi.org/10.1186/s12896-017-0369-y 